\title{
Exploring the potential of fungal-bacterial consortium for low-cost biodegradation and detoxification of textile effluent
}

\author{
Harshad Lade ${ }^{1}$, Avinash Kadam², Diby Paul ${ }^{1 *}$, and Sanjay Govindwar ${ }^{3}$ \\ ${ }^{1}$ Konkuk University, Korea \\ Department of Environmental Engineering \\ ${ }^{2}$ Kyungpook National University, Korea \\ Department of Environmental Engineering \\ ${ }^{3}$ Shivaji University, India \\ Department of Biochemistry \\ *Corresponding author's e-mail: dibypaul@live.com
}

Keywords: fungal-bacterial consortium, wheat bran, textile effluent, decolorization, biodegradation, detoxification.

\begin{abstract}
In the present study, the enrichment and isolation of textile effluent decolorizing bacteria were carried out in wheat bran (WB) medium. The isolated bacterium Providencia rettgeri strain HSL1 was then tested for decolorization of textile effluent in consortium with a dyestuff degrading fungus Aspergillus ochraceus NCIM 1146. Decolorization study suggests that $A$. ochraceus NCIM 1146 and P. rettgeri strain HSL1 alone removes only 6 and $32 \%$ of textile effluent American Dye Manufacturing Institute respectively in $30 \mathrm{~h}$ at $30 \pm 0.2^{\circ} \mathrm{C}$ of microaerophilic incubation, while the fungal-bacterial consortium does $92 \% \mathrm{ADMI}$ removal within the same time period. The fungal-bacterial consortium exhibited enhanced decolorization rate due to the induction in activities of catalytic enzymes laccase (196\%), lignin peroxidase (77\%), azoreductase $(80 \%)$ and NADH-DCIP reductase (84\%). The HPLC analysis confirmed the biodegradation of textile effluent into various metabolites. Detoxification studies of textile effluent before and after treatment with fungal-bacterial consortium revealed reduced toxicity of degradation metabolites. The efficient degradation and detoxification by fungal-bacterial consortium pre-grown in agricultural based medium thus suggest a promising approach in designing low-cost treatment technologies for textile effluent.
\end{abstract}

\section{Introduction}

Textile industry effluent consists of a mixture of organic compounds of complex structure which results in increasing pollution when released into the environment. The discharge of such untreated textile effluent into the water resources, such as rivers and lakes, alters $\mathrm{pH}$, increases $\mathrm{COD}$, TOC and gives intense coloration. The presence of textile dyestuff even in low concentration in the effluent is highly visible and undesirable (Nigam et al. 1996). Moreover, the minor release of such effluent into water streams may change their appearance and makes them of no use. This possesses a great threat to the environment and also causes the ecotoxic hazards (Sharma 2009). Therefore, to minimize the adverse environmental hazards and human health effects, the treatment of textile effluent becomes necessary before being discharged into water bodies. However, the efficient removal of dyes from textile effluent still remains a major environmental challenge.

There are numerous physicochemical and biological treatment processes available for the decolorization and biodegradation of textile effluent. The physicochemical processes that include adsorption, advanced oxidation and coagulation have been used successfully to remove dyestuff from textile effluent (Djordjevic et al. 2014, Vandevivere et al. 1998). However, most of them present the complication associated with high cost of reagents used, a huge amount of sludge generation and possible toxicity of treated effluents (Davies et al. 2005). The removal of acidic dye from an aqueous solution by sorption on dead fungus biomass was also reported (Kahraman et al. 2012). Alternately, decolorization of textile effluent by microorganisms such as fungi, bacteria as well as their consortium have been shown highly efficient with the generation of less-toxic degradation metabolites (Parshetti et al. 2007, Kalyani et al. 2008, Lade et al. 2012).

As the textile effluent is composed of a mixture of structurally different dyes, the biodegradation system to be used must have the ability to decolorize wide variant of dyes. The low decolorization efficiency of individual bacteria or fungi towards a mixture of dyes and high rates of complex dyestuff degradation by fungal-bacterial consortium thus suggest an alternative approach for the efficient treatment of textile effluent (Qu et al. 2010). Recent studies have shown that the fungal-bacterial 
consortium might attack the dye molecule at different positions or utilize intermediate metabolites produced by one organism for further mineralization into non-toxic form (Keck et al. 2002). It has been reported that the fungal-bacterial consortium consisted of A. orchaceus NCIM 1146 and Pseudomonas sp. SUK1 showed more enhanced degradation and detoxification of textile effluent than the individual cultures (Kadam et al. 2011, Lade et al. 2012). Decolorization of azo dyes by bacteria produces toxic aromatic amines due to the reductive cleavage by azoreductase; while fungi do not generate amines due to asymmetric cleavage of azo dyes or its degradation metabolites by oxidases (Lade et al. 2012). Therefore, the use of mixed enzymatic systems from the fungal-bacterial consortium for enhanced decolorization and detoxification of azo dyes has been suggested. Hence, more of such fungal-bacterial consortiums should be reported and it is extremely necessary in concern of ecofriendly biological detoxification of textile dyes.

However, the key factor which limits the use of biodegradation processes for large-scale treatment of textile effluent is a higher cost of the defined growth medium. The previous dyes degradation studies often used such growth mediums v.z. nutrient broth, which is expensive to use at commercial levels. Thus, to minimize the cost of microbial growth medium and make the biodegradation processes more economical, the use of agricultural wastes such as microbial growth medium has been suggested. Several agricultural wastes and their by-products such as corn cob, rice bran, wheat straw, wheat bran etc. are rich in carbon contents and abundantly available at low-cost (Singh et al. 2012). Recently, agricultural waste wheat bran has been reported to be a growth medium for the microbial consortium and their subsequent use in biodegradation of toxic azo dye Trypan Blue (Lade et al. 2015). In this view, the easily available agricultural waste WB has been further explored as a low-cost medium for growth of $P$. rettgeri strain HSL1 bacterium and their use in consortium with fungus $A$. ochraceus NCIM 1146 for degradation and detoxification of textile effluent. As part of our study, the lowcost means growing the bacterial culture in WB medium.

\section{Materials and methods}

\section{Chemicals, textile effluent, and microbial growth medium}

2,2'-Azino-bis (3-ethylbenzothiazoline-6-sulfonic acid) (ABTS), n-propanol, methyl red, nicotinamide adenine dinucleotide (NADH), dichlorophenol indophenols (DCIP) and potato dextrose broth (PDB) were procured from HiMedia Laboratories Pvt. Ltd. (Mumbai, MS, India). Chloranil, dimethylformamide, aniline-2-sulfonic, lower melting point agarose and normal melting point agarose were purchased from Sigma-Aldrich (St. Louis, MO, USA). All the chemicals used were of highest purity available and of an analytical grade. The effluent from local textile industry utilizing structurally different dyestuff was collected in the airtight plastic can and transported to the laboratory. Prior to decolorization study, the collected effluent was filtered through Whatman grade no. 1 filter paper $(11 \mu \mathrm{m})$ to remove large suspended particles and stored at $4 \pm 1^{\circ} \mathrm{C}$ until further use. The agricultural waste WB medium was prepared as described earlier, $\mathrm{pH}$ adjusted to 7.0 and used as growth medium for enrichment and isolation of textile effluent decolorizing bacteria (Lade et al. 2015). Potato dextrose broth (PDB) having the composition $\mathrm{g} \mathrm{l}^{-1}$ of potatoes infusion 200.0, dextrose 20.0 and yeast extract $5.0(\mathrm{pH} \mathrm{5.8)}$ was used as growth medium for fungal culture.

\section{Isolation and identification of potent textile effluent decolorizing bacteria}

Dye contaminated soil was collected from local textile industry site (Ichalkaranji, MS, India) and inoculated (1.0 gm) into a $250 \mathrm{~mL}$ Erlenmeyer flask containing $100 \mathrm{~mL}$ of WB medium amended with $1 \%$ textile effluent. A total of five consecutive enrichments of $48 \mathrm{~h}$ each at $30 \pm 0.2^{\circ} \mathrm{C}$ under microaerophilic incubation were performed in WB medium containing $1-5 \%$ textile effluent for acclimatization of microorganisms. The acclimatized broth culture was then streak inoculated on $5 \%$ textile effluent amended WB agar plates and incubated at $30 \pm 0.2^{\circ} \mathrm{C}$ for $24 \mathrm{~h}$. After incubation, the morphologically different colonies were selected and screened for decolorization of textile effluent. The potent bacterial strain that could decolorize high concentration of textile effluent was selected and identified through $16 \mathrm{~S}$ rRNA gene sequences analysis. The screened bacterium was grown in WB medium $(\mathrm{pH} 7.0)$ at $30 \pm 0.2^{\circ} \mathrm{C}$ for $24 \mathrm{~h}$ and genomic DNA was extracted (Ausubel et al. 1997). Polymerase chain reaction (PCR) amplification of the 16S rRNA genes was performed using the forward primer RDB1-GC clamped (F58-CGCCGCCGCGCCCCGCGCCCG GCCCGCCGCCGCGGCCGCAGTTTGATCCTGGCTCAG) and reverse primer RDB2 (GGACTACCAGGGTATCTAAT) (Eden et al. 1991, Muyzer et al. 1993). The purified PCR amplicons were then sequenced and compared with the $16 \mathrm{~S}$ rRNA gene sequences available in the GenBank database at the National Centre for Biotechnology Information (NCBI) using the basic local alignment search tool BLASTN 2.2.28 algorithm (Zhang et al. 2000).

\section{Phylogenetic analysis of textile effluent decolorizing bacterial isolate}

The screened bacterial isolate nucleotide sequence was aligned with CLUSTAL W (Thompson et al. 1994). The partial 16S rRNA sequence was further analyzed by phylogenetic tree using the Molecular Evolutionary Genetic Analysis (MEGA) software version 4.0. The tree was generated with the Neighbor-Joining algorithm and bootstrap for 550 re-sampling to ensure robustness and reliability of trees constructed (Tamura et al. 2007). Furthermore, the assembled partial 16S rRNA gene sequence of identified bacterial isolate has been deposited in public sequence repository NCBI GenBank using the BankIt sequence submission tool.

\section{Fungal-bacterial consortium}

A. ochraceus NCIM 1146 fungus was procured from National Center for Industrial Microorganisms, National Chemical Laboratories (Pune, MS, India) and the P. rettgeri strain HSL1 bacterium isolated in this study was used to make fungal-bacterial consortium. The fungus culture A. ochraceus NCIM 1146 was selected based on the previous reports suggesting its textile effluent degrading potential in consortium with bacteria (Lade et al. 2012, Kadam et al. 2011). The pre-growth of $A$. ochraceus NCIM 1146 was carried out into a $250 \mathrm{~mL}$ Erlenmeyer flask containing $100 \mathrm{~mL}$ of PDB according to a previous report (Lade et al. 2012). For the pre-growth of bacterial isolate, $P$. rettgeri strain HSL1, $100 \mu \mathrm{L}$ of stock 
culture was inoculated in $100 \mathrm{~mL}$ of WB medium $(\mathrm{pH} 7.0)$ and incubated for $24 \mathrm{~h}$ at $30 \pm 0.2^{\circ} \mathrm{C}$ under microaerophilic and aerobic conditions. The fungal-bacterial consortium was prepared by aseptically transferring the equal volumes $(50 \mathrm{~mL})$ of $96 \mathrm{~h}$ grown $A$. ochraceus NCIM 1146 and $24 \mathrm{~h}$ grown $P$. rettgeri strain HSL1 cultures into a $250 \mathrm{~mL}$ Erlenmeyer flasks and used for decolorization of textile effluent.

\section{Decolorization of textile effluent}

All the decolorization experiments were performed into the $250 \mathrm{~mL}$ Erlenmeyer flask containing $100 \mathrm{~mL}$ of pre-grown A. ochraceus NCIM 1146 and $P$. rettgeri strain HSL1 cultures alone as well as their fungal-bacterial consortium $(100 \mathrm{~mL})$. An equal quantity of textile effluent was added into the pre-grown individual and fungal-bacterial consortium culture flasks and the effect of microaerophilic or aerobic incubation, incubation temperatures $\left(20,30,37,40\right.$ and $\left.50 \pm 0.2^{\circ} \mathrm{C}\right)$ and pre-grown culture broth $\mathrm{pH}$ (3-12) on decolorization performance were investigated.

Aliquots of the culture supernatant $(2 \mathrm{~mL})$ and control medium were withdrawn at regular time intervals; suspended particles were removed by adding an equal volume of methanol followed by centrifugation $\left(7500 \times g\right.$ for $\left.20 \mathrm{~min}, 4 \pm 0.2^{\circ} \mathrm{C}\right)$. The decolorization was then monitored by UV-vis spectrophotometer (Hitachi U-2800; Hitachi, Tokyo, Japan) and calculated using the American Dye Manufacturer's Institute (ADMI 3WL) tristimulus filter method (Chen et al. 2003). All the decolorization experiments were run in triplicate. The pre-grown culture medium which was without textile effluent (biotic control) and uncultured medium containing textile effluent (abiotic control) were also investigated under the same conditions.

\section{Mineralization analysis and characterization of textile effluent}

The physicochemical characterization of textile effluent for the reduction in chemical oxygen demand (COD) before and after the decolorization was carried out as per the standard methods (APHA 2012). Reduction in the amount of total organic carbon (TOC) was measured using Hach DR 2700 spectrophotometer (Hach Co., Loveland, CO, USA). A detailed characterization of textile effluent for total dissolved solids (TDS), total suspended solids (TSS), total solids (TS) and total hardness $\left(\mathrm{CaCO}_{3}\right)$ was performed by employing the standard methods (APHA 2012). Table 1 shows the physico-chemical characteristics of textile effluent. The aromatic amines formed after decolorization of textile effluent were estimated as previously described (Marik et al. 2003).

Table 1. Physico-chemical characteristics of textile effluent

\begin{tabular}{|l|l|}
\hline Parameter & Value \\
\hline COD $\left(\mathrm{mg} \mathrm{l}^{-1}\right)$ & $3750 \pm 15.0$ \\
\hline TOC $\left(\mathrm{mg} \mathrm{l}^{-1}\right)$ & $3812 \pm 8.0$ \\
\hline Aromatic amines $(\mathrm{mM})$ & n.d. \\
\hline TDS $\left(\mathrm{mg} \mathrm{l}^{-1}\right)$ & $2950 \pm 10.0$ \\
\hline TSS $\left(\mathrm{mg} \mathrm{l}^{-1}\right)$ & $475 \pm 5.0$ \\
\hline TS $\left(\mathrm{mg} \mathrm{l}^{-1}\right)$ & $3220 \pm 10.0$ \\
\hline Total hardness $\left(\mathrm{mg} \mathrm{l}^{-1}\right)$ & $185 \pm 5.0$ \\
\hline
\end{tabular}

Values are mean of three experiments \pm standard deviation (SD). n.d. $=$ Not detected

\section{Biodegradation analysis}

The extraction of metabolites after complete decolorization of textile effluent by the fungal-bacterial consortium was performed as per earlier report (Lade et al. 2012). The extracted metabolites were subject to HPLC analysis and also used for detoxification studies. HPLC analysis of textile effluent and its extracted metabolites was performed on Waters 2690 instrument (Waters Corporation, Milford, MA, USA) equipped with a $\mathrm{C}_{18}$ column (Symmetry, $4.6 \times 250 \mathrm{~mm}$ ) kept at $30^{\circ} \mathrm{C}$. A total of $10 \mu \mathrm{l}$ filtered textile effluent and extracted metabolites dissolved in methanol were manually injected into the column at a flow rate of $0.50 \mathrm{~mL} \mathrm{~min}$. The elution conditions and instrument parameters used include methanol as a mobile phase for $10 \mathrm{~min}$ and UV detector set at $280 \mathrm{~nm}$.

\section{Enzymatic analysis}

The extraction of enzymes after decolorization of textile effluent by the fungal-bacterial consortium and from control broth cultures (without effluent) was carried out according to the earlier report (Lade et al. 2012). The activities of both oxidative and reductive enzymes were assayed spectrophotometrically at room temperature $\left(30 \pm 1{ }^{\circ} \mathrm{C}\right)$. Laccase activity was estimated by monitoring the oxidation of $1 \mathrm{mM}$ ABTS in sodium acetate buffer (100 mM, pH 4.9) at $420 \mathrm{~nm}$ (Eggert et al. 1996). Lignin peroxidase activity was determined by monitoring the oxidation of n-propanol with the formation of propanaldehyde at $300 \mathrm{~nm}$ (Hatvani and Mecs 2001). Azoreductase activity was measured by monitoring the absorbance decrease of Methyl red at $430 \mathrm{~nm}$ (Chen et al. 2005). The NADH-DCIP reductase activity was estimated by measuring the reduction of DCIP at $590 \mathrm{~nm}$ (Salokhe and Govindwar 1999). All enzyme assays were run in triplicate and the average rates were calculated. The protein content was determined by Lowry et al. (1951) method with bovine serum albumin as the standard.

\section{Detoxification studies}

The genotoxicity of textile effluent and its degradation metabolites was performed by Comet assay to examine the effect on nuclear integrity of root meristem of Allium cepa bulb (Acharya et al. 2008, Kulkarni et al. 2014). Genotoxicity was measured with the comet properties such as tail length, tail movement and \% DNA in tail with the application 212 TriTek Comet Score version 1.5. The phytotoxicity testing of textile effluent and its degradation metabolites was carried out at room temperature $\left(30 \pm 1^{\circ} \mathrm{C}\right)$ on two kinds of common agricultural crops Sorghum vulgare (monocot) and Phaseolus mungo (dicot) according to a previous report (Lade et al. 2012).

\section{Statistical analysis}

The statistical analysis was performed by one-way analysis of variance (ANOVA) with Tukey-Kramer multiple comparisons test using the software SPSS 17.0 (SPSS, Chicago, IL, USA).

\section{Results and discussion}

\section{Isolation and identification of textile effluent decolorizing bacteria}

Enrichment of environmental bacteria from dye contaminated soils was performed in WB medium by acclimatizing the broth culture to increasing concentration (1 to 5\%) of textile effluent. A potent bacterial isolate which decolorized 
a higher concentration of textile effluent in WB medium was selected and the molecular identification was carried out. The nucleotide blast analysis of partial 16S rRNA gene sequence of screened bacterial isolate with the sequences available in NCBI GenBank database suggested that the strain has $98 \%$ identification similarities with the 16S rRNA gene sequence of the Providencia rettgeri. Thus, the selected bacterial isolate has been designated as $P$. rettgeri strain HSL1. The phylogenetic relationship between the $P$. rettgeri strain HSL1 and its closest related strain sequences available at NCBI GeneBank database was constructed (Fig. 1). The partial 16S rRNA gene sequence of $P$. rettgeri strain has been deposited in the GenBank database under the accession number JX853768.1. The isolation of Providencia species has been previously reported from dye contaminated soils and known to degrade textile dye Red HE3B in consortium with Ps. aeuroginosa strain BCH (Phugare et al. 2011a). Similarly, isolation, screening, and identification of textile dye Solvent Red 5B degrading P. staurti strain Ebt SPG has been reported (Kadam et al. 2013). All these previous studies suggest that Providencia species are well known in degradation of textile dyes. Thus, there is an opportunity to elaborate low-cost degradation potential of $P$. staurti strain HSL1 in consortium with known dyes degradation fungus A. ochraceus NCIM 1146 for complete degradation and detoxification of textile effluent.

\section{Decolorization of textile effluent}

The biodegradation capacity of microorganisms can be tested by examining its potential to decolorize structurally different dyestuffs in the form of textile effluent. Therefore, decolorization of textile effluent was investigated by using individual pre-grown cultures of $A$. ochraceus NCIM 1146 fungi, $P$. rettgeri strain HSL1 bacterium and their fungal-bacterial consortium. The higher biomass of both the cultures $A$. ochraceus NCIM 1146 and $P$. rettgeri strain HSL1 was observed under aerobic incubation conditions at $30 \pm 0.2^{\circ} \mathrm{C}$ (Dry weight $6.41 \mathrm{~g} \mathrm{~L}^{-1}$ in $96 \mathrm{~h}$ and $1.16 \mathrm{~g} \mathrm{~L}^{-1}$ in $24 \mathrm{~h}$ ) as compared to microaerophilic incubation (Dry weight

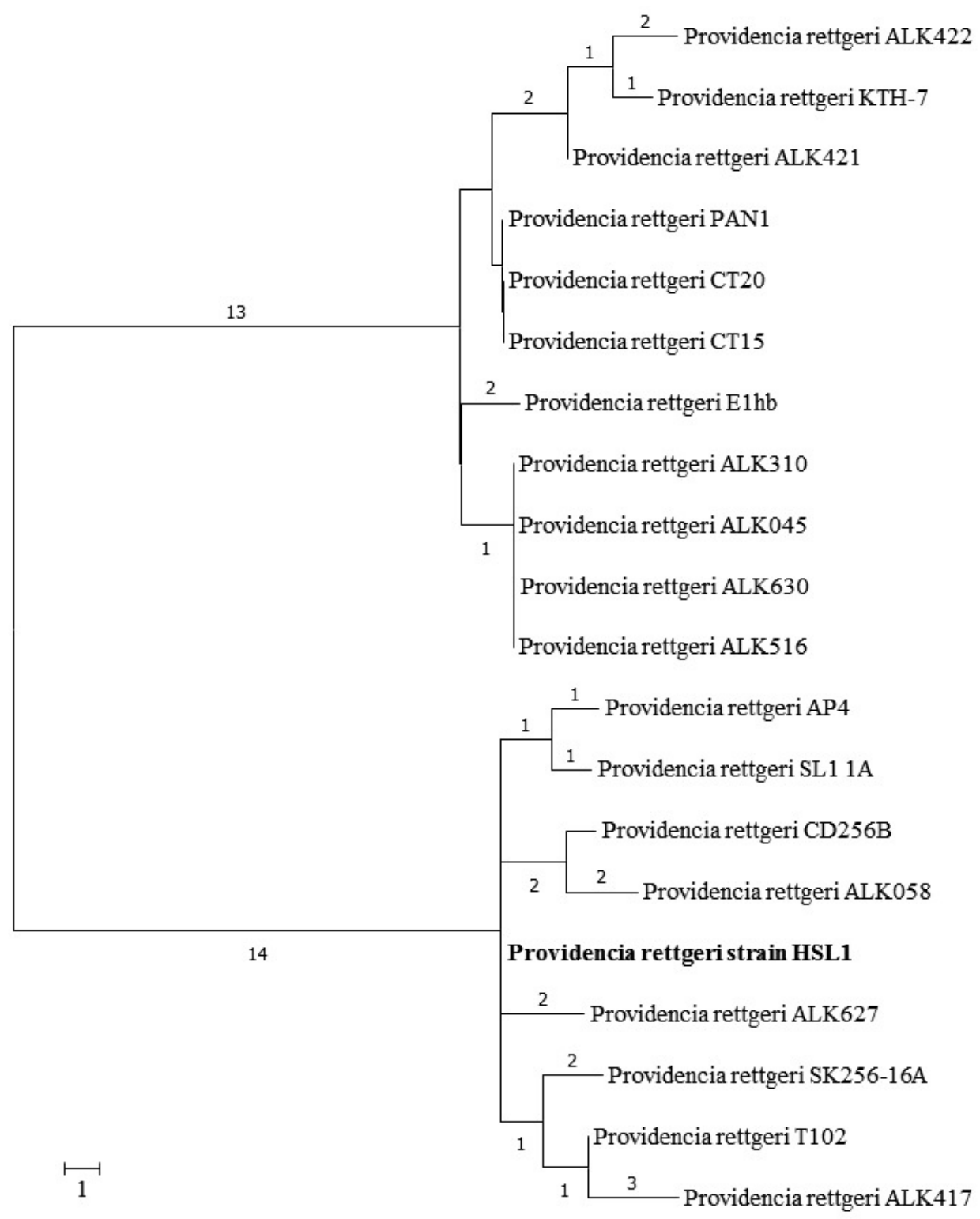

Fig. 1. Phylogenetic analysis of the $16 \mathrm{~S}$ rRNA gene sequence of $P$. rettgeri strain HSL1 with its closest related strain sequences available at NCBI GeneBank database 
$4.41 \mathrm{~g} \mathrm{~L}^{-1}$ and $0.42 \mathrm{~g} \mathrm{~L}^{-1}$ ) respectively. The aerobic pre-grown A. ochraceus NCIM 1146 culture showed 6\% ADMI removal of textile effluent within $30 \mathrm{~h}$ under microaerophilic conditions at $30 \pm 0.2^{\circ} \mathrm{C}$ while microaerophilic pre-grown culture showed $4 \%$ ADMI removal within same time under similar conditions. On the other hand, aerobic pre-grown $P$. rettgeri strain HSL1 culture showed $18 \%$ ADMI removal of textile effluent within $30 \mathrm{~h}$ at $30 \pm 0.2^{\circ} \mathrm{C}$ while microaerophilic pre-grown culture showed 32\% ADMI removal within same time under similar conditions. However, negligible decolorization of textile effluent by both the aerobic and microaerophilic grown culture was observed under aerobic incubation conditions. Hence, the aerobic incubation condition for pre-growth of $A$. ochraceus NCIM 1146 culture and microaerophilic for pre-growth of $P$. rettgeri strain HSL1 culture were adopted for further textile effluent decolorization study.

The results of the decolorization by a fungal-bacterial consortium under microaerophilic incubation condition showed higher ADMI removal $(92 \%)$ within $30 \mathrm{~h}$ at $30 \pm 0.2^{\circ} \mathrm{C}$ (Fig. 2b) in contrast to only 4\% ADMI removal under aerobic condition (Fig. 2a). Moreover, individual A. ochraceus NCIM 1146 and $P$. rettgeri strain HSL1 showed only 6 and $32 \%$ AMDI removal under microaerophilic incubation conditions within the same time while 3 and $2 \%$ when incubated in aerobic conditions. Decolorization of textile effluent using both the individual cultures was further investigated for $48 \mathrm{~h}$ under similar conditions, but no complete ADMI removal was observed (data not shown). It is known that enzyme driven bacterial decolorization of azo dyes is inhibited by the presence of oxygen generally due to the competition in oxidation of $\mathrm{NADH}$ with dissolved oxygen or azo bond $(-\mathrm{N}=\mathrm{N}-)$ as the electron receptor (Stolz 2001). This perception has been well supported in a previous study, where decolorization of textile effluent by fungal-bacterial consortium was strongly inhibited under aerobic incubation conditions (Lade et al. 2012). Therefore, microaerophilic incubation conditions are necessary for decolorization of textile effluent containing azo dyes and hence adopted further in this study.

These results of the study suggest that average rate of decolorization performance by the fungal-bacterial consortium is significantly higher than that of individual cultures. The higher decolorization performance by fungal-bacterial consortium might be due to the synergistic reaction of individual cultures in the consortium (Chen and Chang 2007). Similar findings were reported in our previous study, where enhanced decolorization of textile industry effluent (98\% ADMI removal in $35 \mathrm{~h}$ ) was achieved by a fungal-bacterial consortium-AP of $A$. ochraceus NCIM 1146 fungi and Pseudomonas sp. SUK1 bacterium when compared with its constituent pure strains (Lade et al. 2012). It is suggested that in microbial consortium the individual strains may attack dye molecule at different positions or may utilize the metabolites produced by co-existing strains for further a) Aerobic decolorization condition

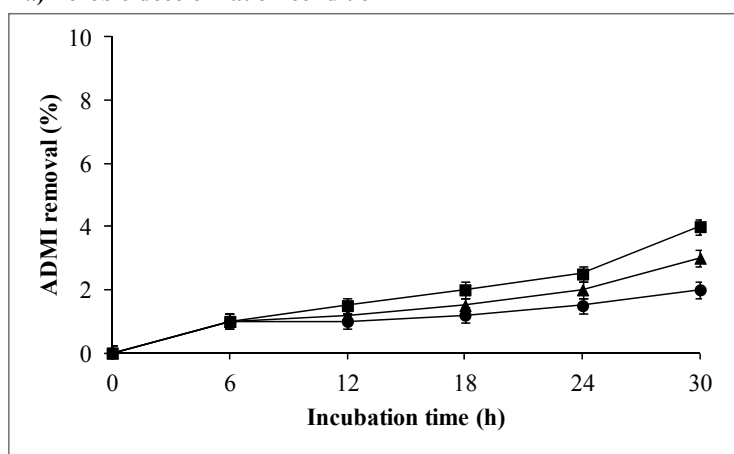

b) Microaerophilic decolorization condition

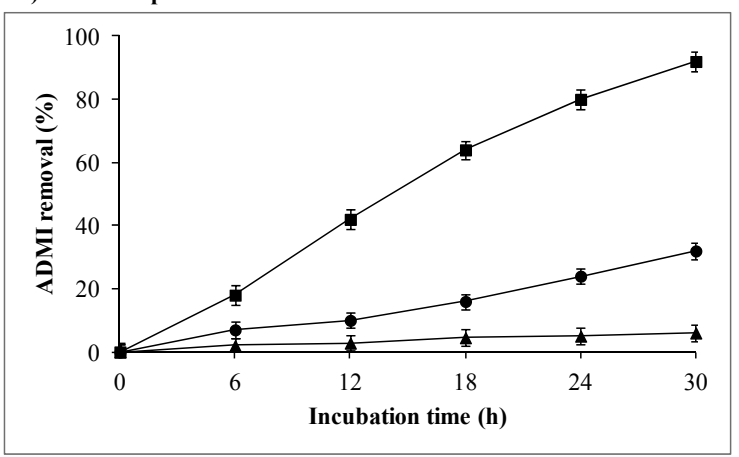

Fig. 2. Decolorization of textile effluent by individual $A$. ochraceus NCIM $1146(\longrightarrow$ ), P. rettgeri strain HSL1 ( $\bullet-)$ and their fungal-bacterial consortium (- - ) under a) aerobic, and b) microaerophilic conditions

(Data points indicate the mean of three independent replicates, standard error of mean is indicated by error bars)
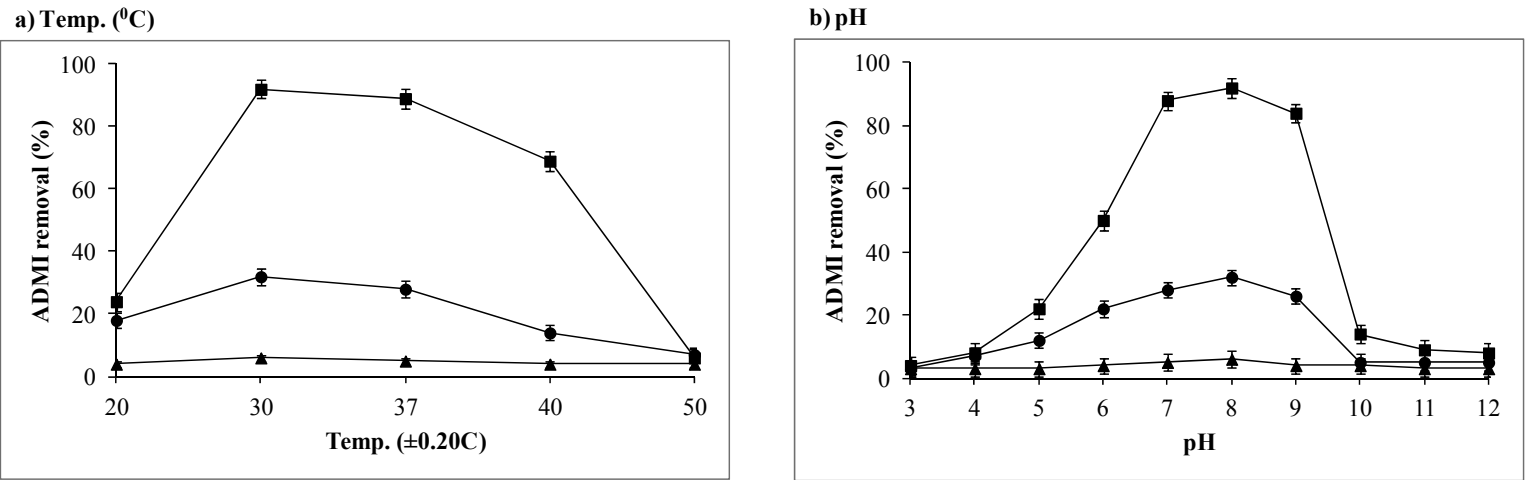

Fig. 3. Effect of a) incubation temperature and b) pre-grown culture medium $\mathrm{pH}$ on decolorization of textile effluent

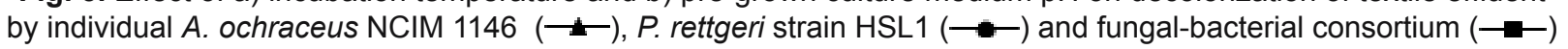
under microaerophilic conditions

(Data points indicate the mean of three independent replicates, standard error of mean is indicated by error bars) 
decomposition which results in increased rate of decolorization than single strains (Moosvi et al. 2007).

\section{Optimization of decolorization conditions}

In view of optimizing the decolorization process and providing an affordable treatment technology for textile effluent, the effects of environmental conditions on decolorization performance were investigated. Decolorization of dyes is known to be associated with the growth and enzyme activities of microorganisms at optimum temperatures. Decolorization of textile effluent at various temperatures suggests that a maximum ADMI removal of $92 \%$ was achieved at $30 \pm 0.2^{\circ} \mathrm{C}$ within $30 \mathrm{~h}$ by the fungal-bacterial consortium (Fig. 3a). Both the individual cultures $A$. ochraceus NCIM 1146 and $P$. rettgeri strain HSL1 also showed a maximum ADMI removal of 6 and $32 \%$ at $30 \pm 0.2^{\circ} \mathrm{C}$. Further increase in the temperature of up to $37 \pm 0.2^{\circ} \mathrm{C}$ resulted in marginal reduction in the decolorization performance of fungal-bacterial consortium (89\% ADMI removal) as well as individual cultures $A$. ochraceus NCIM $1146(5 \%)$ and $P$. rettgeri strain HSL1 (28\%). Our previous study also showed that the fungal-bacterial consortium achieved higher decolorization at $30 \pm 0.2^{\circ} \mathrm{C}$ while incubation at lower and higher temperatures than the optimum marginally reduced decolorization rates (Lade et al. 2012). Therefore, it was clear that, though higher ADMI removal often corresponds with the optimum incubation temperature, the fungal-bacterial consortium was well adapted to a range of temperatures for efficient textile effluent decolorization.

The original $\mathrm{pH}$ of individual pre-grown $A$. ochraceus NCIM 1146 and $P$. rettgeri strain HSL1 culture medium in this study was 7.80 and 7.95 respectively (without any $\mathrm{pH}$ adjustment). The results of the initial pre-grown culture medium $\mathrm{pH}$ on textile effluent decolorization showed that the fungal-bacterial consortium was able to decolorize the textile effluent at a broad range of $\mathrm{pH}(7.0-9.0)$, however, the optimum $\mathrm{pH}$ for maximum ADMI removal $(92 \%)$ was found to be 8.0 (Fig. 3b). The decolorization performance was decreased at lower $\mathrm{pH}(3-6)$ and higher $\mathrm{pH}(10-12)$. In the case of individual cultures, $A$. ochraceus NCIM 1146 showed a maximum ADMI removal of $6 \%$ at $\mathrm{pH}$ value of 7.85 , whereas $32 \%$ ADMI removal was observed at a $\mathrm{pH}$ value of 8.0 by $P$. rettgeri strain HSL1. The $\mathrm{pH}$ is more likely related to the transport of dye molecules across the cell membrane, which was considered as the rate limiting step for the decolorization (Lourenco et al. 2000). These observations suggest that the fungal-bacterial consortium could decolorize the textile effluent at alkaline $\mathrm{pH}$, which is a normal characteristic of textile effluent.

\section{Characterization and biodegradation of textile effluent}

Textile effluent is characterized by the presence of high COD and TOC contents. The strength of these parameters is known to be greatly depending upon the textile processing and treatment technology used (Chen et al. 2003). The result of the textile effluent after decolorization by fungal-bacterial consortium showed 92.0\% ADMI removal within $30 \mathrm{~h}$ with a significant reduction in COD $(90 \%)$ and TOC $(52 \%)$ contents under microaerophilic incubation condition (Table 2). However, individual A. ochraceus NCIM 1146 and $P$. rettgeri strain HSL1 removes only 6 and $32 \%$ ADMI with very less reduction in COD (12 and 21\%) and TOC (6 and 26\%), respectively. These results suggest that the strength of environmentally important parameters treated with fungal-bacterial consortium was significantly lower than that of untreated textile effluent. The COD of textile effluent mainly depends on the organic matters present and reduction after treatment with fungal-bacterial consortium indicates its mineralization. Additionally, the complete absence of aromatic amines in the fungal-bacterial consortium treated textile effluent samples ultimately indicates its detoxification. Thus, the ultimate aim of biodegradation to reduce the concentration of toxic pollutants from textile effluent has been fulfilled using the fungal-bacterial consortium with low-cost growth medium and thus can be elaborated further up to reactor scale for the treatment of textile effluent onsite. The real market cost evaluation of agricultural waste wheat bran has been already highlighted by the low-cost of WB medium (Lade et al. 2015).

\section{Biodegradation analysis}

The HPLC chromatogram of textile effluent showed the presence of four major peaks at retention times of 3.256, 3.546, 4.130 and $4.245 \mathrm{~min}$ and eight minor peaks at retention times of $4.489,4.693,5.840,6.081,6.450,6.630,7.725$ and $7.701 \mathrm{~min}$ (Fig. 4a). However, the metabolites extracted after complete decolorization of textile effluent $(30 \mathrm{~h})$ by fungal-bacterial consortium showed the disappearance of several peaks as seen in the case of untreated textile effluent and the appearance of two major peaks at retention time of 3.514 and $4.086 \mathrm{~min}$ (Fig. 4b). The formation of four minor peaks in decolorized metabolites was also observed which was not seen in the untreated textile effluent. This significant difference between the untreated textile effluent and its decolorized metabolites HPLC elution profile support the biodegradation of textile effluent into various metabolites.

Table 2. Physico-chemical analysis of textile effluent after treatment with individual cultures and fungal-bacterial consortium under microaerophilic conditions

\begin{tabular}{|l|l|l|l|}
\hline \multirow{2}{*}{ Parameter } & \multicolumn{3}{|c|}{ Value (After treatment for 30 h) } \\
\cline { 2 - 4 } & A. ochraceus NCIM 1146 & P. rettgeri strain HSL1 & Fungal-bacterial consortium \\
\hline COD $\left(\mathrm{mg} \mathrm{l}^{-1}\right)$ & $3300 \pm 15.0$ & $2950 \pm 7.0$ & $370 \pm 4.0$ \\
\hline TOC $\left(\mathrm{mg} \mathrm{l}^{-1}\right)$ & $3580 \pm 6.0$ & $2835 \pm 6.0$ & $1820 \pm 5.0$ \\
\hline ADMI removal $(\%)$ & $06.0 \pm 1.0$ & $32.0 \pm 2.0$ & $92.0 \pm 2.0$ \\
\hline Aromatic amines $(\mathrm{mM})$ & n.d. & 0.31 & n.d. \\
\hline
\end{tabular}

Values are mean of three experiments \pm standard deviation (SD)

n.d. = Not detected 


\section{Enzymatic analysis}

The major mechanisms involved in the biodegradation of textile dyestuff are driven by various biotransformation enzymes. The role of such enzymes from various fungi, bacteria as well as their consortium have been well documented in biodegradation of textile dyestuff and effluent (Parshetti et al. 2007, Lade et al. 2012). In order to get the additional insight into the degradation process by the fungal-bacterial consortium, the activities of crude oxidoreductive enzyme were monitored. The enzymatic analysis revealed significant induction in the activities of both oxidative as well as reductive enzymes v.z. laccase $196 \%$, lignin peroxidase $77 \%$, azoreductase $80 \%$ and NADH-DCIP reductase $84 \%$, which suggests the biotransformation of dyes by oxidative and reductive methods (Table 3 ). The predominant roles of azo reductase and NADH-DCIP have been previously reported for enhanced degradation of azo dyes and textile effluent by a fungal-bacterial consortium consisting of A. ochraceus NCIM 1146 and Pseudomonas sp. SUK1 (Lade et al. 2012, Kadam et al. 2011). Similarly, bacterial consortium SDS of Providencia sp. SDS and Ps. aeuroginosa strain $\mathrm{BCH}$ showed the inductive pattern of oxidoreductive enzymes laccase, azo reductase and NADH-DCIP in the degradation of textile effluent (Phugare et al. 2011b). It has also been reported that fungal lignin peroxidases show higher oxidative degradation potential towards azo dyes (Parshetti et al. 2007, Pasti-Grigsby et al. 1992).

a) Before treatment

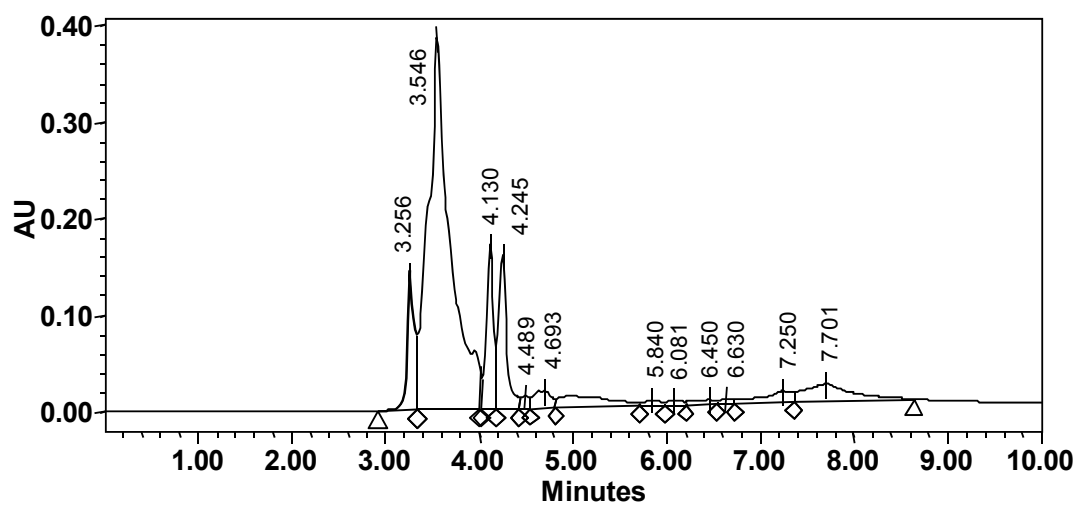

b) After treatment

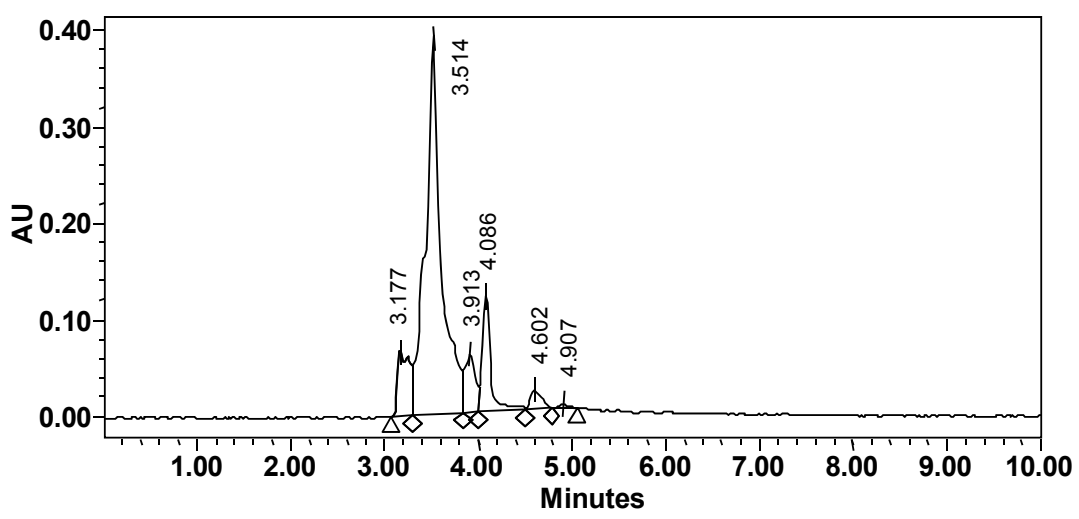

Fig. 4. HPLC elution profile of a) untreated textile effluent, and b) its decolorization metabolites obtained after treatment with fungal-bacterial consortium under microaerophilic conditions

Table 3. Enzyme activity analysis of fungal-bacterial consortium during decolorization of textile effluent under microaerophilic conditions

\begin{tabular}{|l|l|l|}
\hline Enzymes & Control $(0 \mathrm{~h})$ & Test $(30 \mathrm{~h})$ \\
\hline Laccase $^{1}$ & $1.25 \pm 0.144$ & $3.7 \pm 0.145$ \\
\hline Lignin peroxidase $^{2}$ & $2.16 \pm 0.33$ & $3.83 \pm 1.66$ \\
\hline Azoreductase $^{3}$ & $2.5 \pm 0.288$ & $4.5 \pm 0.270$ \\
\hline NADH-DCIP reductase & 4 & $35 \pm 2.88$ \\
\hline
\end{tabular}

Values are mean of three experiments, \pm SEM, significantly different from control cells at ${ }^{*} P<0.001$ by one-way analysis of variance (ANOVA) with Tukey Kramer comparison test

${ }^{1} \mu \mathrm{M}$ of ABTS oxidized $\mathrm{min}^{-1} \mathrm{~mL}$ of enzyme ${ }^{-1} \mathrm{mg}$ of protein ${ }^{-1}$

${ }^{2} \mu \mathrm{M}$ of $\mathrm{n}$-propanol oxidized $\mathrm{min}^{-1} \mathrm{~mL}$ of enzyme $\mathrm{m}^{-1} \mathrm{mg}$ of protein ${ }^{-1}$

${ }^{3} \mu \mathrm{M}$ of Methyl red reduced $\mathrm{min}^{-1} \mathrm{~mL}$ of enzyme $\mathrm{mg}^{-1} \mathrm{mg}$ of protein ${ }^{-1}$

${ }^{4} \mu \mathrm{M}$ of DCIP reduced $\mathrm{min}^{-1} \mathrm{~mL}$ of enzyme $\mathrm{mg}^{-1} \mathrm{mg}$ of protein ${ }^{-1}$ 


\section{Detoxification studies}

Despite the fact that untreated textile effluent may cause serious environmental and human health hazards, it is being disposed of into the natural water resources such as rivers and lakes. The water from such resources is normally used for agriculture purposes like irrigating the crop plants. In this way, these toxicants enter agricultural crops and further the human body through the food chain. Thus, it is of great concern to assess the toxicity of treated textile effluent by means of genotoxicity and phytotoxicity tests before disposing of it into the natural resources.

The application of Comet assay is considered to be a rapid, sensitive, inexpensive and simple method for detecting DNA damage on root meristem of individual cells of $A$. cepa (Chakraborty et al. 2009, Phugare et al. 2011a). The results of Comet assay demonstrated that the root meristem of $A$. cepa bulbs showed genetic damage in the presence of textile effluent as the chromosomal material integrity was disturbed as well as it was oozing out in the form of bulging in nuclear membrane showing comet like structure (Fig. 5b); while this was not seen with meristem treated with distilled water (Fig. 5a) as well as textile effluent degradation metabolites (Fig. 5c). The damage of meristematic cells treated with degradation metabolites was significantly less than that of cells treated with textile effluent as an intact cell without comet was observed. Similar observations were reported where textile dye scarlet R 24 damage the chromosomal material integrity in $A$. cepa bulbs, whereas dye metabolites degraded by Lichen Permelia perlata reduce the toxic effect (Kulkarni et al. 2014).

The results of control as treated with distilled water and degradation metabolites were compared and showed decreased tail length (13 and $16 \mu \mathrm{m})$, tail movement (0.60 and 0.66) and $\%$ DNA (1.9 and 3.65\%) in the tail of comet in comparison to that of textile effluent (Table 4). The values of control and degradation metabolites are very close to each other suggesting complete detoxification of treated effluent. These results reveal the integrity of cell due to decreased toxicity of treated effluent by the fungal-bacterial consortium. However, untreated textile effluent showed very high values for genotoxic parameters such as $118 \mu \mathrm{m}$ tail length, 10 of the tail moment and 14\% DNA in tail suggesting its toxic nature. Textile dyes such as Direct red 73 and effluent are known to possess strong genotoxic effect on A. cepa DNA in root meristems (Kadam et al. 2014, Phugare et al. 2011b).

The relative sensitivities of $S$. vulgare and $P$. mungo seeds towards textile effluent and its degradation metabolites have a)

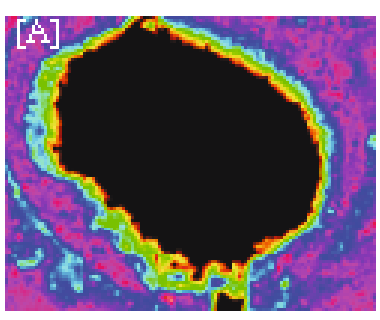

b)

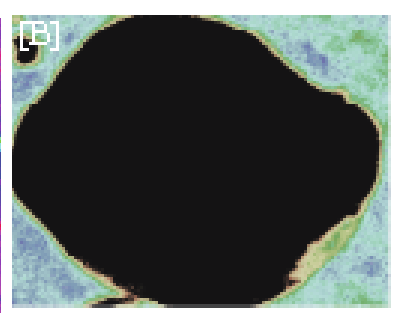

c)

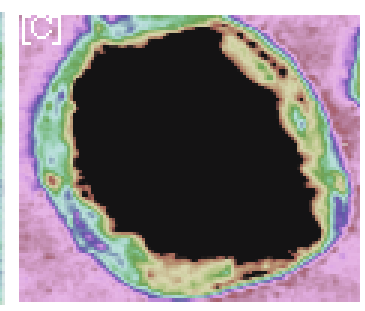

Fig. 5. Analysis of comets observed a) control as treated with distilled water, b) treated with textile effluent, and c) treated with degradation metabolites of textile effluent after treatment with fungal-bacterial consortium under microaerophilic conditions

Table 4. Genotoxicity analysis of textile effluent and its degradation metabolites obtained after treatment with fungal-bacterial consortium under microaerophilic conditions

\begin{tabular}{|l|l|l|l|}
\hline Comet characteristics & Distilled water & Textile effluent & Degradation metabolites \\
\hline Tail length $(\mu \mathrm{m})$ & $13 \pm 0.57$ & $118 \pm 0.33$ & $16 \pm 1.73$ \\
\hline Tail moment & $0.60 \pm 0.15$ & $10 \pm 0.66$ & $0.66 \pm 0.19$ \\
\hline$\%$ DNA in tail & $1.90 \pm 0.20$ & $14 \pm 1.00$ & $3.65 \pm 0.19$ \\
\hline
\end{tabular}

Values are mean of three experiments, \pm SEM. significantly different from the control

Table 5. Phytotoxicity analysis of textile effluent and its degradation metabolites obtained after treatment with fungal-bacterial consortium

\begin{tabular}{|l|l|l|l|l|l|l|}
\hline \multirow{2}{*}{ Samples } & \multicolumn{3}{|c|}{ S. vulgare } & \multicolumn{3}{c|}{ P. mungo } \\
\cline { 2 - 7 } & $\begin{array}{l}\text { Germination } \\
(\%)\end{array}$ & $\begin{array}{l}\text { Shoot length } \\
(\mathrm{cm})\end{array}$ & $\begin{array}{l}\text { Root length } \\
(\mathrm{cm})\end{array}$ & $\begin{array}{l}\text { Germination } \\
(\%)\end{array}$ & $\begin{array}{l}\text { Shoot length } \\
(\mathrm{cm})\end{array}$ & $\begin{array}{l}\text { Root length } \\
(\mathrm{cm})\end{array}$ \\
\hline Distilled water & 100 & $8.2 \pm 0.6$ & $3.1 \pm 0.4$ & 100 & $9.5 \pm 0.7$ & $4.0 \pm 0.4$ \\
\hline Textile effluent & 20 & $3.9 \pm 0.3^{*}$ & $1.1 \pm 0.2^{*}$ & 30 & $4.3 \pm 0.3^{*}$ & $1.2 \pm 0.2^{*}$ \\
\hline Degradation metabolites & 100 & $7.9 \pm 0.5$ & $2.8 \pm 0.4$ & 100 & $9.3 \pm 0.5$ & $3.9 \pm 0.3$ \\
\hline
\end{tabular}

Values are mean of three experiments, \pm SEM. Seeds germinated textile effluent are significantly different from control (distilled water) at ${ }^{*} \mathrm{P}<0.001$ by one-way analysis of variance (ANOVA) with Tukey-Kramer comparison test 
been summarized in Table 5. The results of phytotoxicity study showed that there was an inhibition of germination in textile effluent soaked seeds for both the S. vulgare and P. mungo plants by 20 and $30 \%$ respectively. Additionally, shoot (3.9 and $4.3 \mathrm{~cm})$ and root length $(1.1$ and $1.2 \mathrm{~cm})$ of these germinated plants were also found to be lower than of those germinated in distilled water and in degradation metabolites. However, good germination rate $(100 \%)$, as well as significant growth in the shoot $(7.9$ and $9.3 \mathrm{~cm})$ and root length $(2.8$ and $3.9 \mathrm{~cm})$ of $S$. vulgare and $P$. mungo grew in extracted degradation metabolites were observed. These findings confirm the reduced phytotoxicity of treated textile effluent by the fungal-bacterial consortium.

Based on the results of genotoxic effects on DNA damage of $A$. серa and phytotoxicity to common agricultural plants, it can be concluded that the textile effluent possesses toxicity which in turn gets significantly reduced by treatment with the fungal-bacterial consortium.

\section{Conclusions}

The present study explores the potential of fungal and bacterial cultures to grow in low-cost agricultural products or waste derived medium and decolorize textile effluent. The fungal-bacterial consortium exhibited higher decolorization of textile effluent at alkaline $\mathrm{pH}$ and at $30 \pm 0.2^{\circ} \mathrm{C}$ temperature under microaerophilic incubation conditions, which are normal operational conditions used in conventional effluent treatment plants. The synergetic actions of co-cultures in the fungal-bacterial consortium resulted in mineralization of textile effluent as well as nullified its genotoxicity and phytotoxicity. Therefore, the fungal-bacterial consortium seems to have potential application in designing low-cost treatment technologies for mineralization and detoxification of textile effluent. However, further pilot scale study using fungal-bacterial consortium bioreactor is needed to demonstrate its commercial application for treatment of textile effluent at large scale.

\section{Acknowledgments}

This paper was supported by the KU Research Professor Program of Konkuk University.

\section{References}

Acharya, V.M.M., Jena, S., Panda, K.K. \& Panda, B.B. (2008). Aluminium induced oxidative stress and DNA damage in root cells of Allium cepa L., Ecotoxicology and Environmental Safety, 70, 2, pp. 300-310.

APHA (2012). Standard method for the examination of water and wastewater, American Public Health Association, Washington, DC, USA 2012.

Ausubel, F.M., Brent, R., Kingston, R.E., Moore, D.D., Seidman, J.G., Smith, J.A. \& Struhl, K. (1997). Preparation and analysis of DNA, in: Current Protocols in Molecular Biology, Moore, D.D. \& Dowhan, D. (Eds.), John Wiley and Sons, New York, NY, USA, pp. 2.0.1-2.0.3.

Chakraborty, R., Mukherjee, A.K. \& Mukherjee, A. (2009). Evaluation of genotoxicity of coal fly ash in Allium cepa root cells by combining comet assay with the Allium test, Environmental Monitoring and Assessment, 153, 1-4, pp. 351-357.
Chen, B.Y. \& Chang, J.S. (2007). Assessment upon species evolution of mixed consortia for azo dye decolorization, Journal of the Chinese Institute of Chemical Engineers, 38, 3-4, pp. 259-266.

Chen, H., Hopper, S.L. \& Cerniglia, C.E. (2005). Biochemical and molecular characterization of an azoreductase from Staphylococcus aureus, a tetrameric NADPH-dependent flavoprotein, Microbiology, 151, Pt 5, pp. 1433-1441.

Chen, K.C., Wu, J.Y., Liou, D.J. \& Hwang, S.C. (2003). Decolorization of the textile dyes by newly isolated bacterial strains, Journal of Biotechnology, 101, 1, pp. 57-68.

Davies, L.C., Carias, C.C., Novais, J.M. \& Martins-Dias, S. (2005). Phytoremediation of textile effluents containing azo dye by using Phragmites australis in a vertical flow intermittent feeding constructed wetland, Ecological Engineering, 25, 5, pp. 594-605.

Djordjevic, D., Stojiljkovic, D. \& Smelcerovic, M. (2014). Adsorption kinetics of reactive dyes on ash from town heating plant, Archives of Environmental Protection, 40, 3, pp. 123-135.

Eden, P.A., Schmidt, T.M., Blakemore, R.P. \& Pace, N.R. (1991). Phylogenetic analysis of Aquaspirillum magnetotacticum using polymerase chain reaction amplified 16S rRNA-specific DNA, International Journal of Systematic Bacteriology, 41, 2, pp. 324-325.

Eggert, C., Temp, U. \& Eriksson, K.E. (1996). The ligninolytic system of the white rot fungus Pycnoporus cinnabarinus: purification and characterization of the laccase, Applied and Environmental Microbiology, 62, 4, pp. 1151-1158.

Hatvani, N. \& Mecs, I. (2001). Production of laccase and manganese peroxidase by Lentinus edodes on malt containing by product of the brewing process, Process Biochemistry, 37, 5, pp. 491-496.

Kadam, A.A., Kulkarni, A.N., Lade, H.S. \& Govindwar, S.P. (2014). Exploiting the potential of plant growth promoting bacteria in decolorization of dye Disperse Red 73 adsorbed on milled sugarcane bagasse under solid state fermentation, International Biodeterioration \& Biodegradation, 86, part C, pp. 364-371.

Kadam, A.A., Lade, H.S., Patil, S.M. \& Govindwar, S.P. (2013). Low cost $\mathrm{CaCl}_{2}$ pretreatment of sugarcane bagasse for enhancement of textile dyes adsorption and subsequent biodegradation of adsorbed dyes under solid state fermentation, Bioresource Technology, 132, pp. 276-284.

Kadam, A.A., Telke, A.A., Jagtap, S.S. \& Govindwar, S.P. (2011). Decolorization of adsorbed textile dyes by developed consortium of Pseudomonas sp. SUK1 and Aspergillus ochraceus NCIM-1146 under solid state fermentation, Journal of Hazardous Material, 189, 1-2, pp. 486-494.

Kahraman, S., Kuru, F., Dogan, D. \& Yesilada, O. (2012). Removal of indigo carmine from an aqueous solution by fungus Pleurotus ostreatus, Archives of Environmental Protection, 38, 3, pp. 51-57.

Kalyani, D.C., Patil, P.S., Jadhav, J.P. \& Govindwar, S.P. (2008). Biodegradation of reactive textile dye red BLI by an isolated bacterium Pseudomonas sp. SUK1, Bioresource Technology, 99, 11, pp. 4635-4641.

Keck, A., Rau, J., Reemtsma, T., Mattes, R., Stolz, A. \& Klein, J. (2002). Identification of quinoide redox mediators that are formed during the degradation of naphthalene-2-sulfonate by Sphingomonas xenophaga BN6, Applied and Environmental Microbiology, 68, 9, pp. 4341-4349.

Kulkarni, A.N., Kadam, A.A., Kachole, M.S. \& Govindwar, S.P. (2014). Lichen Permelia perlata: A novel system for biodegradation and detoxification of disperse dye Solvent Red 24, Journal of Hazardous Material, 276, pp. 461-468.

Lade, H., Kadam, A., Paul, D. \& Govindwar, S. (2015). A Low-Cost Wheat bran medium for biodegradation of the benzidine-based carcinogenic dye Trypan Blue using a microbial consortium, International Journal of Environmental Research and Public Health, 12, 4, pp. 3480-3505. 
Lade, H.S., Waghmode, T.R., Kadam, A.A. \& Govindwar, S.P. (2012). Enhanced biodegradation and detoxification of disperse azo dye Rubine GFL and textile industry effluent by defined fungal-bacterial consortium, Internatinal Biodeteriotayion \& Biodegradation, 72, pp. 94-107.

Lourenco, N.D., Novais, J.M. \& Pinheiro, H.M. (2000). Reactive textile dye colour removal in a sequencing batch reactor, Water Science and Technology, 42, 5-6, pp. 321-328.

Lowry, O.H., Rosebrough, N.J., Farr, A.L. \& Randall, R.J. (1951). Protein measurement with the Folin phenol reagent, Journal of Biological Chemistry, 193, 1, pp. 265-275.

Marik, J., Song, A. \& Lam, K.S. (2003). Detection of primary aromatic amines on solid phase, Tetrahedron Letters, 44, 23, pp. 4319-4320.

Moosvi, S., Kher, X. \& Madamwar, D. (2007). Isolation, characterization and decolorization of textile dyes by a mixed bacterial consortium JW-2, Dyes and Pigments, 74, 3, pp. 723-729.

Muyzer, G., de Waal, E.C. \& Uitterlinden, A.G. (1993). Profiling of complex microbial populations by denaturing gradient gel electrophoresis analysis of polymerase chain reaction-amplified genes coding for 16S rRNA, Applied and Environmental Microbiology, 59, 3, pp. 695-700.

Nigam, P., Banat, I.M., Singh, D. \& Marchant, R. (1996). Microbial process for the decolorization of textile effluent containing azo, diazo and reactive dyes, Process Biochemistry, 31, 5, pp. 435-442.

Parshetti, G.K., Kalme, S.D., Gomare, S.S. \& Govindwar, S.P. (2007). Biodegradation of reactive blue-25 by Aspergillus ochraceus NCIM-1146, Bioresource Technology, 98, 18, pp. 3638-3642.

Pasti-Grigsby, M.B., Paszczynski, A., Goszczynski, S., Crawford, D.L. \& Crawford, R.L. (1992). Influence of aromatic substitution patterns on azo dye degradability by Streptomyces spp. and Phanerochaete chrysosporium, Applied and Environmental Microbiology, 58, 11, pp. 3605-3613.

Phugare, S.S., Kalyani, D.C., Patil, A.V. \& Jadhav, J.P. (2011a). Textile dye degradation by bacterial consortium and subsequent toxicological analysis of dye and dye metabolites using cytotoxicity, genotoxicity and oxidative stress studies, Journal of Hazardous Material, 186, 1, pp. 713-723.
Phugare, S.S., Kalyani, D.C., Surwase, S.N. \& Jadhav, J.P. (2011b). Ecofriendly degradation, decolorization and detoxification of textile effluent by a developed bacterial consortium, Ecotoxicology and Environmental Safety, 74, 5, pp. 1288-1296.

Qu, Y., Shi, S., Ma, F. \& Yan, B. (2010). Decolorization of reactive dark blue K-R by the synergism of fungus and bacterium using response surface methodology, Bioresource Technology, 101, 21, pp. 8016-8023.

Salokhe, M.D. \& Govindwar, S.P. (1999). Effect of carbon source on the biotransformation enzyme in Serratia marcescens, World Journal of Microbiology and Biotechnology, 15, 2, pp. 259-263.

Sharma, V.K. (2009). Aggregation and toxicity of titanium dioxide nanoparticles in aquatic environment-A review, Journal of Environmental Science and Health. Part A, Toxic/ Hazardous Substances Environmental Engineering, 44, 14, pp. 1485-1495.

Singh, R., Kapoor, V. \& Kumar, V. (2012). Utilization of agro-industrial wastes for the simultaneous production of amylase and xylanase by thermophilic Actinomycetes, Brazilian Journal of Microbiology, 43, 4, pp. 1545-1552.

Stolz, A. (2001). Basic and applied aspects in the microbial degradation of azo dyes, Applied Microbiology and Biotechnology, 56, 1-2, pp. 69-80.

Tamura, K., Dudley, J., Nei, M. \& Kumar, S. (2007). MEGA4: Molecular Evolutionary Genetics Analysis (MEGA) software version 4.0, Molecular Biology and Evolution, 24, 8, pp. 1596-1599.

Thompson, J.D., Higgins, D.G. \& Gibson, T.J. (1994). CLUSTAL W-improving the sensitivity of progressive multiple sequence alignment through sequence weighting, position specific gap penalties and weight matrix choice, Nucleic Acids Research, 22, 22, pp. 4673-4680.

Vandevivere, P.C., Bianchi, R. \& Verstraete, W. (1998). Treatment and reuse of wastewater from the textile wet-processing industry: Review of emerging technologies, Journal of Chemical Technology and Biotechnology, 72, 4, pp. 289-302.

Zhang, Z., Schwartz, S., Wagner, L. \& Miller, W. (2000). A greedy algorithm for aligning DNA sequences, Journal of Computational Biology, 7, 1-2, pp. 203-214. 